UDC 355/359+35.073.53+339

JEL Classification: B59

DOI: 10.15587/2312-8372.2020.201260

Kubiv 5.,
Balanyuk Y.

\title{
DEVELOPMENT OF A MATHEMATICAL MODEL OF CONFLICT BETWEEN THE PARTIES IN THE IMPLEMENTATION OF THE OFFSET TRANSACTION
}

Об’єктом дослідження даної роботи є конфлікт інтересів сторін при реалізащї офсетних угод. Одним з найбільш проблемних місць при реалізащї офсетних угод є те, що можуть мати місце найрізноманітніші раптові подіі, форс-мажорні обставини тощо - явища, які неможливо докладно описати та з припустимою точністю передбачити в повному обсязі. Крім того, офсетний контракт представляє собою конфлікт інтересів продавия та покупия. В ході дослідження були використані методи гуманітарного та природно-наукового підходу, завдяки чому конфлікту дано нове тлумачення. Він розглядається як спосіб взаємодії складних систем. Показано, що конфлікт не синонім конфронтащї, а це спосіб подолання протиріч і обмежень, спосіб взаємодї складних систем - явище неминуче, нормальне. Звичайно, конфлікт передбачає боротьбу, але, перш за все, конфлікт передбачає саме взаємодію. Показано, що конфлікт не може розглядатися як задача оптимізачї, оскільки при рівних ресурсах сторін конфлікт буде припинено через повне виснаження обох сторін, а при нерівних - поразку більш слабкої сторони з імовірністю одиниця. Також конфлікт не може бути розв'язаний і в рамках теорї адаптації. Проведено короткий порівняльний аналіз можливостей застосування різновидів марківських процесів та ступеня їх адекватності реальним процесам супроводження офсетних угод на різних етапах. Запропоновано математичну модель конфлікту між сторонами. В моделі процес розвитку конфлікту є розгалуженим напівмарківським процесом, перехідні та фінальні ймовірності якого залежать від співвідношення ресурсів сторін. Крім того, конфлікт представляє послідовність узгожених дій сторін $і$, по суті, є керованим квазіперіодичним процесом з елементами стохастичності. Досліджено результуючі виграші сторін конфлікту при різновидах їх співробітництва та суперництва. Запропонована модель може бути застосована для моделювання процесів розвитку та реалізації офсетних програм та виграшів сторін-учасників.

ключові слова: гуманоміка, коменсащійна угода, стохастична система, теорія конфліктів, офсетна політика, керований процес, марківський процес.

\section{Introduction}

The last two decades of the twentieth century are marked by a noticeable expansion of product markets in developed countries and developing countries, and the emergence, or rather, their reproduction in countries with economies in transition. The most dynamic segment of the commodity market is the market for the purchase of weapons and military equipment (WME).

In the context of increasing competition in the WME markets, the problem of maintaining and strengthening one's place in such a high-tech and at the same time specific market as the world WME market is becoming very urgent. To solve this problem, it is necessary to actively develop new approaches to promoting existing and newly created models on the WME market, new methods of attracting importers and interacting with them [1]. One of the most developed methods of long-term interaction is offset - an agreement between the exporter and the importer with the simultaneous conclusion of some counter (compensation) agreements between them. When implementing offset agreements, first of all, it is necessary to determine fundamentally the issues of organizing interaction between the parties «exporter - importer» and establishing strict liability conditions when concluding long-term agreements between the parties [2]. In addition, the offset contract constitutes a conflict of interest between the seller and the buyer with the associated risks. Mutually beneficial relations between the parties of the offset program are asymptotically effective by definition, that is, with a probability of one. Separate offset transactions that are not interconnected are a random process with wins and losses. The parameters and asymptotic characteristics of this process are almost impossible to predict for a more or less acceptable period. Therefore, the urgent issue is the development of competitive opposition models. Moreover, the emphasis solely on economism (abstract economic mechanism or economic mainstream) as a single driving force of offset programs is objectively not just fruitless, but essentially counterproductive. Thus, the humanitarian aspect of economic relations, in relation to 
long-term offset programs and individual offset agreements, prompts researchers to the following actions [3]:

- theoreticians - to research and prove the roots of rational human behavior in the economy in general and in the field of trade in particular, to try to explain and understand the nature of human irrationality;

- practitioners - look for specific ways to organize such types of cooperation that would encourage the parties to increase responsibility to each other and enhance their economic relations.

In [4], the author investigates the humanitarian context of offset policy and proposed a business model of compensation transactions. An unresolved issue is the study of the parties' gain in the varieties of their cooperation and rivalry. Therefore, the object of research is the conflict of interests of the parties in the implementation of offset agreements. The aim of research is to develop a model for predicting the development of relations between the parties in the implementation of offset agreements.

\section{Methods of research}

Let's consider this problem of organizing cooperation in the field of military-technical cooperation.

The objects of offset transactions in the arms markets, as a rule, are modern high-tech systems that are created for several years with the absorption of huge resources [5]. Such systems are modified many times and are in service throughout the life of a generation, and sometimes much longer. The essential property of such systems - conflict and poor predictability of long-term consequences - is too often not taken into account, which led and continues to lead to fatal consequences $[6,7]$.

Systemic methodology combines humanitarian and natural-scientific methods, thanks to which the conflict is given a new interpretation. It is considered as a way of interaction of complex systems. Moreover, a conflict is not something exceptional, not a synonym for confrontation, but a way to overcome contradictions and limitations, a way of interaction of complex systems - an inevitable, normal phenomenon. Of course, a conflict involves a fight, but, above all, a conflict involves interaction [8].

There is no single universally accepted definition of conflict. On the one hand, a conflict is a competition in which the parties strive to achieve incompatible positions. This contradicts the concept of the possibility of resolving the conflict through the agreement [7]. The development of technologies, especially computer and information technologies, has brought mankind to a new level of the development spiral. Now almost all conflicts are somehow related to technology, including robotics. Technical devices of any degree of complexity serve the person, so anthropocentrism (as well as economism, which has been repeatedly mentioned above) is so selfish regarding the conflict is unacceptable. Both at the highest level - interstate relations and political leadership - and at the lowest levels in the infrastructure, the technical component of the conflict is very important.

The theory of conflict does not claim to be complete and the scientific community. This is a systems engineering theory which goal is to solve practical problems. It is based on the system engineering concept outlined in $[8,9]$.

The problems of forming and evaluating the offset policy of states in international markets, in particular, the con- clusion and implementation of offset contracts, is a very important and specific area of financial and economic activity. When concluding an offset contract, a wide variety of sudden events, force majeure circumstances, etc. can take place - phenomena that can't be described in detail and predicted with acceptable accuracy in full. In addition, an offset contract as a practice of counterclaims, compensation by the exporter of part of the cost to the importer of arms for their purchase objectively represents a conflict of interests between the seller and the buyer with the corresponding risks.

\section{Research results and discussion}

In view of the foregoing, the aim of resolving a conflict in a competitive environment and other risks is to manage the process of protecting an offset transaction. Let's consider the mathematical basis of this problem.

Conflict can't be seen as an optimization task. With equal resources of the parties, «optimality» means the end of the conflict due to the complete depletion of both sides, and with unequal resources - the defeat of the weaker side with a probability of one. In this case, the remainder of the resource:

$$
R_{\text {res }}=\Psi(|R|-|r|),
$$

where $R, r,|R| \succ|r|$ - the initial resources of the strengths and weaknesses, respectively; $\succ-$ symbol of the dominance of one side over the other; $\Psi(f)$ - known functional (usually quadratic) of a function $f$.

Theoretically, in a conflict, a possible gain is lesser. However, to achieve a gain with a probability higher than the value of the second order of smallness, it is necessary to have disposal resources of the same order with the resources of the attacking side.

Conflict with a smart adversary can't be resolved within the framework of the theory of adaptation. With its active actions, the enemy with a probability tending to unity will achieve maximum gain. But we, adapting to conditions that are constantly getting worse, will end up in the most disadvantageous situation.

Therefore, the main tasks that must be solved to achieve this aim are:

- analysis of possible conflict strategies and the selec-

tion of the most promising strategies for this task;

- choice of the mathematical apparatus for describing

the processes of conflict development;

- development of a mathematical model of conflict;

- obtaining asymptotic performance characteristics.

According to the general theory of conflict, the processes of confrontation between the parties are described by differential-difference equations or equations with arguments deviating [10]. This assumption is true for discrete systems with a delay, what are the financial time series, in particular, the time processes for concluding and implementing offset agreements.

In scientific and technical sources with open access [7, 8], conflict is considered as a way of interaction of complex systems. The developed apparatus of the theory of conflict resolution allows to determine the purposefulness of systems, their true (and not those that are declared, demonstrated and reflected) performance criteria, to develop a better line of behavior in accordance with these criteria. 
In general:

$$
\left\{\begin{array}{l}
z_{i d s}^{\prime}(t)=f_{1}\left(t, z_{i d s}(t), \ldots, z_{i d s}\left(t-\tau_{1}\right), u_{1}(t), v_{2}\left(t-\tau_{2}\right), \xi(t)\right) ; \\
z_{i c m}^{\prime}(t)=f_{2}\left(t, z_{i c m}(t), \ldots, z_{i c m}\left(t-\tau_{2}\right), u_{2}\left(t-\tau_{2}\right), v_{1}(t), \eta(t)\right),
\end{array}\right.
$$

where $z_{i d s}, z_{i c m}$ - state vectors of the systems of action of the exporter and importer, respectively; $u_{1}(t)$ and $u_{2}(t)-$ control vectors in $S_{i d s}$ and $S_{i c m}$, respectively; $v_{1}(t)$ - vector of actions $S_{i d s}$ on $S_{i c m} ; v_{2}(t)$ - vector of actions $S_{i c m}$ on $S_{i d s}$; $\xi(t), \eta(t)$ - vectors of random perturbations acting on $S_{\text {ids }}$ and $S_{i c m}$, respectively; $\tau_{1}, \tau_{2}$ - delays in the data entering the system $S_{i d s}$ and $S_{i c m}$, accordingly.

The efficiency $E_{1}$ of the $S_{i d s}$ system and the efficiency $E_{2}$ of the $S_{i c m}$ system in the observation interval in the general case are nonlinear functionals of states $z_{i d s}, z_{i c m}$ and vectors $\xi(t), \eta(t)$, respectively. From equations (1) follows their mutual dependence.

If to take into account the factor of normalization of random processes in large systems [11], then it is possible to apply the Gaussian approximation method in a small neighborhood of the extremum points $E_{1}$ and $E_{2}$ to solve equations (1). In this case, the expressions for the efficiencies are of the form:

$$
\begin{aligned}
& E_{1}=\int_{0}^{T} z_{i d s}(t) \mathrm{d} t, E_{1} \rightarrow \max _{v_{1}}, \\
& E_{2}=\int_{0}^{T} z_{i c m}(t) \mathrm{d} t, E_{2} \rightarrow \max _{v_{2}} .
\end{aligned}
$$

Let's suppose that the goal of each side is to maximize its effectiveness by reducing the effectiveness of the opposing side. However, the result of the efforts will become known only at a time $T$. On the observation interval $0 \leq t \leq T$, it is possible to make better controls $u_{1}(t)$, actions $v_{1}(t)$ and predict the final result, only relying on the assumption of the partner's behavior strategy and data on the current states $z_{i d s}$ and $z_{i c m}$. The inclusion of functions $v_{1}(t)$ in equation (1) means the diversion of part of the resource to the formation of protective or misinforming influences.

Therefore, it is necessary to solve the conflict problem either with an additional criterion for minimizing the share of the resource allocated for protection, or with a restriction on the allowable costs of this share of the resource.

The scheme of the conflict model between the parties $S_{\text {icm }}$ and $S_{i d s}$, modified for the case of applying escalation strategies to pseudo-services (disinformation, false information systems), is shown in Fig. 1. The model of real conflict, as a rule, is non-linear. To obtain asymptotic estimates for a sufficiently large observation interval (with a large number of conflict development options), it is permissible to make step-by-step linearization of the model with extrapolation based on the methods of correlation and regression [12]. To search for extrapolation coefficients of the linearized model, a modified step-by-step procedure is developed with the replacement and forced inclusion of independent variables. In this case, the elimination of the missing variables from the sample $X_{1}, X_{2}, \ldots, X_{p}$ (active resources and pseudoservices) of the missing value $X_{i}, 1 \leq i \leq p$ is not necessary, since it can lead to the loss of information about the vari- ables $X_{1}, X_{2}, \ldots X_{i-1}, X_{i+1}, \ldots X_{p}$ delivered by the element $X_{i}$. Theoretically, it is possible to leave this element in the sample and use the measurements contained in it to calculate the vector of average values $\overrightarrow{\mathbf{X}}$ and the covariance matrix $\mathbf{R}_{\mathbf{X}}$. In a real situation, approximate methods have to be used to obtain this data.

An abstract system based on the theory of conflict provides for active actions to neutralize negative influences. Theoretical models and methods of analysis, forecasting the development of a conflict and optimization of sequences of protective actions against unscrupulous competitors are considered here.

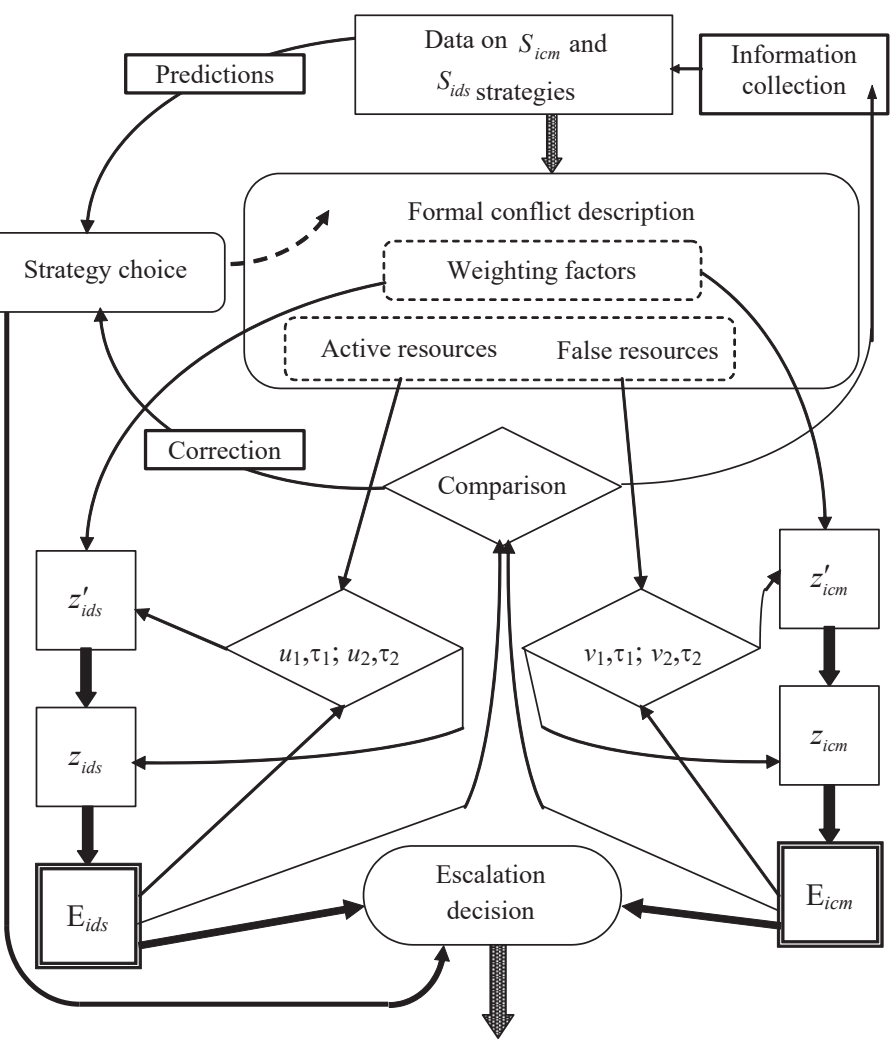

Fig. 1. Linearized stochastic conflict model between the parties

The conflict development process is a branched semiMarkov process, the transitional and final probabilities of which depend on the ratio of the strategic $\left(S_{i d s}, S_{i c m}\right)$ and energy-information $\left(E_{i d s}, E_{i c m}\right)$ resources of the parties. In addition, the conflict as a process of cooperation between partners represents a sequence of concerted actions of the parties and, in fact, is a controlled quasiperiodic process with elements of stochasticity.

\section{Conclusions}

Research result is the prevailing idea of a conflict of interest between participants in offset agreements. It is considered as a way of interaction of complex systems. Moreover, a conflict is not something exceptional, not a synonym for confrontation, but a way to overcome contradictions and limitations, a way of interaction of complex systems - an inevitable, normal phenomenon. Of course, conflict involves struggle, but, above all, conflict involves interaction.

It is shown that the conflict can't be considered as an optimization problem, nor can the conflict be resolved 
within the framework of the adaptation theory. A brief comparative analysis of the possibilities of using varieties of Markov processes and the degree of their adequacy to the real processes of supporting offset transactions at different stages of their evolution is carried out.

A mathematical model of the conflict between the parties is proposed. The resulting winnings of the parties to the conflict were investigated with varieties of their cooperation and rivalry. This model can be used to model the processes of development and implementation of offset programs and the winnings of the parties involved.

\section{References}

1. Chepkov, I. B., Zubariev, V. V., Smirnov, V. O. et. al. (2017). Teoriia ozbroiennia. Naukovo-tekhnichni problemy ta zavdannia. Vol. 5. Voienno-tekhnichna polityka Ukrainy: formuvannia, stan ta shliakhy udoskonalennia. Kyiv: V. D. Dmytra Buraho, 448.

2. Behma, V. M., Mokliak, S. P., Sverhunov, O. O., Tolochnyi, Yu. V. Behma, V. M. (Ed.) (2011). Ofsetna polityka derzhav v umovakh hlobalizatsii. Otsinky ta prohnozy. Kyiv: NISD, 352.

3. Smith, A. (2011). The Theory of Moral Sentiments. Reprint of 1790 London Edition Gutenberg Publishers, 538.

4. Kubiv, S., Balanyuk, Y. (2020). Research of the influence of humanomics on the economic effect of compensation agreements. Technology Audit and Production Reserves, 1 (4 (51)), 51-54. doi: http://doi.org/10.15587/2312-8372.2020.197023
5. Shemaiev, V. M. (2014). Ofsetna polityka u sferi mizhnarodnoho voienno-ekonomichnoho spivrobitnytstva Ukrainy. Fynansi, uchet, banky, 1 (20), 277-284.

6. Maslov, O. (2008). Mirovoi krizis v svete fenomenov novoi real'nosti i global'nye protivorechiya, trebuyushchie razresheniya. Available at: http://www.polit.nnov.ru/2008/04/21/newrealgate

7. Saaty, T. L. (1968). Mathematical Models of Arms Control and Disarmament: Applications of Mathematical Structures in Politics. New York: John Wiley \& Sons, Inc., 190.

8. Druzhinin, V. V., Kontorov, D. S. (1983). Osnovy voennoi sistemotekhniki. Moscow: Izd. Voisk protivovozdushnoi oborony, 416

9. Wentzel, E. S. (1983). Operations Research: a Methodological Approach. Moscow: Mir Publishers, 264.

10. El'sgol'ts, L. E., Norkin, S. B. (1973). Introduction to the Theory and Application of Differential Equations with Deviating Arguments, Vol. 105. Academic Press, 356.

11. Kazakov, I. E. (1977). Statisticheskaya dinamika sistem s peremennoi strukturoi. Moscow: Nauka, 416.

12. Afifi, A. A., Azen, S. P. (1979). Statistical Analysis, Second Edition: A Computer Oriented Approach 2nd Edition. Academic Press, 442.

Kubiv Stepan, PhD, Associate Professor, Kyiv, Ukraine, ORCID: http:// orcid.org/0000-0002-1110-2024, e-mail: sikubiv@ukr.net

Balanyuk Yuriy, PhD, Associate Professor, Department of Information Security, National Aviation University, Kyiv, Ukraine, ORCID: http:// orcid.org/0000-0003-3036-5804, e-mail: lalink@ukr.net 